( $\mathrm{HCl} 0.1 \mathrm{M})$, oxidation $\left(\mathrm{H}_{2} \mathrm{O}_{2} 1 \%\right.$ and $\left.10 \%\right)$, temperature $\left(50^{\circ} \mathrm{C}\right)$ and ultraviolet light $\left(250 \mathrm{w} / \mathrm{m}, 25^{\circ} \mathrm{C}\right)$.

Results All the samples analysed showed considerable biological activity; this biological activity was surprisingly even observed in those samples subjected to strongly stressed conditions. For the reconstituted sample of $10.0 \mathrm{mg} / \mathrm{ml}$, a remaining activity of $52 \%$ was observed. In the case of the $5.0 \mathrm{mg} / \mathrm{ml}$ sample, the remaining activity decreased to $35 \%$.

The biological activity measured using the samples submitted to stress conditions indicated a remaining activity at least equal to the upper concentration studied in the calibration function, i.e, $50 \mu \mathrm{g} / \mathrm{ml}$. These samples were analysed directly, without dilution, because they had been expected to lose their biological activity totally.

Conclusions The biological activity of infliximab solutions of $10.0 \mathrm{mg} / \mathrm{ml}$ and $5.0 \mathrm{mg} / \mathrm{ml}$ in $\mathrm{NaCl} 0.9 \%$ when stored refrigerated at $4{ }^{\circ} \mathrm{C}$ protected from the daylight was maintained at $52 \%$ and $35 \%$ respectively up to 7 days. The biological activity was also shown in infliximab samples submitted to stress conditions. More experiments are currently being conducted to confirm these results.

Acknowledgement Financial support was provided by the Project PI10/00201 (Instituto Carlos III, Ministerio de Economía y Competitividad, Spain). We also want to thank the Hospital Pharmacy Unit of the University Hospital of San Cecilio who kindly supplied all the infliximab samples.

No conflict of interest.

\section{TCH-015 EVALUATION OF THE CHEMICAL AND PHYSICAL STABILITY OF SODIUM DICHLOROACETATE, AN ORPHAN DRUG FOR RARE METABOLIC DISEASES}

doi:10.1136/ejhpharm-2013-000276.206

'V Cascone, ${ }^{2} \mathrm{~A}$ Tomaino, ${ }^{2 \mathrm{P}}$ Florio, ${ }^{2} \mathrm{M}$ Cristani, ' $\mathrm{G}$ Rizza. ${ }^{1} \mathrm{ASP}$ of Ragusa, Hospital Pharmacy, Ragusa, Italy; 'University of Messina, Pharmaceutical-biological Department Faculty of Pharmacy, Messina, Italy

Background Sodium dichloroacetate (Na-DCA), not a patented substance, which is used in the treatment of rare diseases with congenital defects of the pyruvate-dehydrogenase complex (PDHC), produces a marked reduction in acid-base imbalance and lactic acid levels toxic to the brain parenchyma.

Purpose To evaluate the physical-chemical stability of sodium dichloroacetate in aqueous solution.

Materials and Methods Six grammes of sodium dichloroacetate were dissolved in $60 \mathrm{ml}$ of water for injections (WFI). The exact concentration of the solution obtained was calculated by extrapolation from a calibration curve, recording the absorbance value at the wavelength of $198 \mathrm{~nm}$ of suitable standard solutions $(5-50 \mu \mathrm{g} / \mathrm{ml})$ of sodium dichloroacetate dissolved in water for injections (WFI). The solution was divided between 3 dark glass containers. The first container was kept at room temperature (r.t.), the second one in a refrigerator at $+4^{\circ} \mathrm{C}$, the third one in a freezer at $-20^{\circ} \mathrm{C}$. The stability of the samples, kept at different temperatures, was checked at $31,45,54$ and 60 days; for each sample, using appropriate dilution, absorbance values were recorded $(\lambda=198 \mathrm{~nm})$ and through the sodium dichloroacetate calibration curve made daily, the concentrations of the substance being analysed were calculated. The results were expressed as percentages of sodium dichloroacetate in solution.

Results Samples kept at $+4^{\circ} \mathrm{C}$ were stable throughout the observation period. Samples kept at r.t. were stable until 30 days from preparation, while afterwards a slow and gradual decay could be observed. Samples kept at $-20^{\circ} \mathrm{C}$ showed a progressive increase in concentration
Conclusions The observed increase in samples at $-20^{\circ} \mathrm{C}$ can be explained by the formation of a secondary species with a higher extinction coefficient than sodium dichloroacetate. Data suggest that sodium dichloroacetate solutions should not be stored at $-20^{\circ} \mathrm{C}$ or at r.t. for more than 30 days.

No conflict of interest.

\section{TCH-016 EXTENDED CHEMICAL-PHYSICAL STABILITY OF $25 \mathrm{mg} / \mathrm{ml}$ AZACITIDINE SUSPENSION}

doi:10.1136/ejhpharm-2013-000276.207

C Galloni, VG Azzarà, G Loardi. Spedali Civili Hospital, Pharmacy, Brescia, Italy

Background Azacitidine is used for haematological pathologies. The summary of product characteristics (Vidaza) indicates stability of 45 minutes at room temperature and 22 hours if prepared with water for injections (WFI) at $2-8^{\circ} \mathrm{C}$ at reconstitution and refrigerated.

Purpose To assess the chemical-physical stability of azacitidine suspension $25 \mathrm{mg} / \mathrm{ml}$.

Materials and Methods Analysis foflowed an approved protocol.

The validity of the reference material (azacitidine-Sigma Aldrichbatch-SLBD1299V) was checked before starting the analysis.

$100 \mathrm{mg}$ of drug was reconstituted with $4 \mathrm{ml}$ of refrigerated $\left(2-8^{\circ} \mathrm{C}\right)$ WFI. The sample and standard suspension were stored at $5^{\circ} \mathrm{C}$ in a temperature-controlled refrigerator.

For International Conference Harmonization guideline the solution can be considered stable if the \% assay of azacitidine with respect to the initial value is reduced by less than $5 \%$.

Azacitidine concentrations were determined by a stabilityindicating HPLC method under the following conditions: X-Terra $\mathrm{RP} 18$ column $(150 \times 4.6 \mathrm{~mm}, 5 \mu \mathrm{m}) ; 4^{\circ} \mathrm{C}$ autosampler temperature; phosphate buffer $\mathrm{pH}=6.5$ and acetonitrile/water $=40 / 60$ as mobile phase; $0.8 \mathrm{ml} / \mathrm{min}$ flow rate; $230 \mathrm{~nm}$ UV detection; $20 \mu \mathrm{l}$ injection volume.

At these conditions the sample and a standard suspension were analysed at 0/22/24/48/72/96/168 hours.

The $\%$ assay of azacitidine was calculated at each cheque point and the results were compared with the assessed 100\% values for assay at $\mathrm{t}_{0}$

Results The azacitidine assay (\%) determined by HPLC is reported in the table below.

Average values obtained by triplicate injections at each cheque point are reported.

Conclusions The variation of the \% assay of azacitidine with respect to the initial value is less than $5 \%$ for at least 48 hours.

A microbiological study on azacitidine suspension is ongoing at our hospital. Positive results will allow us to use unused azacitidine suspension within 48 hours of reconstitution with considerable cost savings.

\section{Abstract TCH-016 Table 1}

\begin{tabular}{lll}
\hline Time(hour) & \% Azacitidine assay & \% Azacitidine assay vs. t initial value \\
\hline $0 \mathrm{~h}$ & 110.73 & 102.62 \\
$22 \mathrm{~h}$ & 109.97 & 101.92 \\
$24 \mathrm{~h}$ & 107.90 & 100.00 \\
$48 \mathrm{~h}$ & 103.87 & 96.27 \\
$72 \mathrm{~h}$ & 96.01 & 88.98 \\
$96 \mathrm{~h}$ & 101.04 & 93.64 \\
$168 \mathrm{~h}$ & 87.18 & 80.80 \\
\hline
\end{tabular}

No conflict of interest. 